\title{
DOES DEPORTATION INFRINGE RIGHTS?
}

\author{
Kaila Draper
}

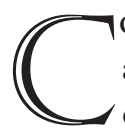

TONSIDER THE MIGRANT who illegally crosses an international border, and suppose that agents of the state she has entered apprehend and detain her and then forcibly return her to her country of origin. ${ }^{1}$ Some opponents of aggressive deportation policies believe that, barring unusual circumstances, this process of using coercion and force to expel the migrant is an infringement of the migrant's rights. Many of those who disagree contend that because a state has a right to enact and enforce immigration restrictions, most deportations do not infringe rights. I maintain that, absent an adequate argument to the contrary, one can conclude presumptively that the typical deportation is an infringement of the migrant's rights. The primary aim of this paper is to show that certain serious arguments to the contrary are inadequate.

\section{ASSUMPTIONS AND PRESUMPTIONS}

The term "deportation" is used in a variety of ways, especially in connection with immigration enforcement in the United States. To avoid confusion, I will simply stipulate that, by "deportation," I mean, "the use of force or coercion (i.e., threat of force) by a state to remove someone from land that it claims as territory" Thus, even "voluntary departure," as that expression is defined in us immigration law, counts as deportation because threats of forcible removal are used to motivate the migrant to "voluntarily" return to her country of origin. ${ }^{2}$

1 Throughout this article, I use expressions like "law" and "illegal" in the broad sense in which some laws do not have authority, and one can behave illegally merely by breaking rules that a government establishes, even if the government is illegitimate or is acting beyond the scope of its authority in establishing the rule. Thus, in saying that a migrant has illegally crossed a border, I do not mean to imply that the migrant has done anything even presumptively wrong.

2 In Us immigration law, "voluntary departure" is a remedy offered to some persons who have been placed in removal proceedings. The individual is permitted to remove themselves from the country but is subject to civil penalties and forcible removal should they fail to do so. Thus, coercion is involved. Even "administrative voluntary departure," which occurs when 
Because the question about deportation that I am addressing is a moral one, it can be answered only from within a moral framework. Of course, like every other moral framework, my own is controversial. But the discussion I am joining presupposes that moral rights exist. Perhaps, then, I will not exclude too many discussants by starting with the following assumptions:

Assumption 1: Any competent person has a moral right to freedom from compulsion-i.e., a right not to be subjected to force or coercion. On my own Lockean conception of moral rights, this right sits at the heart of the right to liberty, which is itself a component of the right to one's own person, but I do not assume that conception here.

Assumption 2: The right to freedom from compulsion is limited. Some uses of coercion and force do not infringe rights. At a minimum, one's own right to freedom from compulsion is limited by the enforcement rights of others. It does not include, for example, the right not to be subjected to necessary and proportionate coercion or force to prevent one from murdering or kidnapping or trespassing or otherwise violating enforceable rights.

Assumption 3: The right to freedom from compulsion is not absolute. Sometimes one can justifiably infringe rights, including the right to freedom from compulsion. Suppose, for example, that I am fleeing a deadly threat and that, without securing your consent, I push you out of my way. I thereby infringe your right not to subjected to force. But if I was reasonably confident that my life depended on pushing you and that pushing you would not cause you or anyone else significant harm, then that infringement of your rights might well have been justified. To oversimplify quite a bit, rights can be infringed justifiably if the expected benefits of the infringement far outweigh the expected costs. ${ }^{3}$

It is important for our purposes to recognize that assumptions 2 and 3 are distinct. To say that the right to freedom from compulsion is limited is to say that not all compulsion infringes that right. To say that the right to freedom from compulsion is not absolute, on the other hand, is to say that some infringements of that right are morally justified. Because our question is whether deportation

someone is stopped at the border and is given the opportunity to retreat, involves detainment. Thus, both count as deportations on my broad use of that term.

3 Following many others, I use the expression "violate a right" to refer specifically to unjustifiably infringing a right. I do not use the term "right" to refer to a mere permission. To possess a right is, at least in part, to possess some valid claim against others. 
infringes rights, assumptions 1 and 2 will play larger roles in our discussion than assumption 3 .

Given assumption 1, there is a presumptive case that the typical deportation does infringe rights. For deportation involves the use of coercion or force to relocate someone against her will. Even if, as some have argued, the right to liberty does not include a right to cross international borders, this presumptive case stands. ${ }^{4}$ For even if there is no right to cross international borders, it does not follow that one's right not to be seized, detained, and moved by means of coercion or force disappears when one crosses an international border. If there is no right to cross international borders, then certain kinds of noncoercive border controls - border walls, for example-might not even presumptively infringe rights, but the issue here is whether deportation infringes rights.

It might be suggested that the presumption that deportation infringes the right to freedom from compulsion can easily be defeated. For it is widely recognized that a (legitimate) state's right to enforce its laws limits other rights, including the right to freedom from compulsion. A state's political authority, including its authority to enact and enforce law, is thought to include its civic authority, which is the authority it has over its own citizens, and its territorial authority. The latter is conventionally regarded as including multiple (possibly overlapping) components. One of these is territorial jurisdiction, which is the authority a state has over anyone who happens to be inside the state's territory. A second component is the authority a state has to control resources within its territory, and a third is the authority a state has to control the movement of persons and objects across its borders. ${ }^{5}$ Obviously a state's civic authority does not limit the rights of foreign migrants. But defenders of deportation can argue that the migrant's rights are limited by the state's territorial authority, including its right to enact and enforce immigration law.

I am not a skeptic about territorial authority, but I see no reason to presume that the scope of that authority includes the right to deport. The fact that states routinely claim such authority provides no such reason, for states have routinely claimed authority they do not possess for millennia. Moreover, states typically do not even try to identify the basis of their alleged authority to deport. If someone subjects you to coercion or force and cannot provide a reasonable basis for doing so, you may presume that they are infringing your rights. The same is true when the agent of coercion or force is a state.

4 See, for example, Miller, "Is There a Human Right to Immigrate?" 11-31.

5 I am following Miller here; see Miller, “Territorial Rights." For a more detailed classification of types of political authority, see Simmons, Boundaries of Authority, 2-6. 


\section{A TAXONOMY OF ARGUMENTS}

Presumptions aside, arguing that the typical migrant's right to freedom from compulsion is not infringed by deportation requires invoking assumption 2 and arguing for the existence of a relevant limit to the right to freedom from compulsion. So far as I can see, four kinds of arguments are possible. My focus in subsequent sections will be on specific instances of two of those four kinds of arguments; but, in this section, I want to briefly discuss the full range of possibilities. Though regrettably superficial, this discussion may be of some use to those who want to assess the overall prospects for a successful argument to the conclusion that the typical deportation does not infringe rights. Here, then, are the four possibilities.

1. Relinquishment arguments. One kind of argument to the conclusion that the typical deportation does not infringe the deported migrant's rights is based on the premise that the deported migrant has voluntarily relinquished (or at least waived) her right not to be deported. I call arguments of this kind "relinquishment arguments." Famously, John Locke tried to ground civic authority in express consent and territorial jurisdiction in tacit consent. ${ }^{6}$ Both of those justifications identify the relinquishment of rights as the source of state authority. But is it plausible to suggest that those who illegally enter, or illegally reside in, a state have somehow consented to that state's having the authority to deport them? Express consent is, of course, a nonstarter. But even an appeal to tacit consent looks unpromising. Tacitly consenting to territorial authority would require one to voluntarily accept benefits from the state, benefits that are offered in exchange for relinquishing that portion of one's rights that must be relinquished if one is to be subject to the territorial authority of the state. Thus, it is difficult to see how the deported migrant could have tacitly consented to her own deportation. Prior to entry, the migrant has not received the benefits of being in the state they eventually enter. Moreover, even the migrant who illegally remains in a state is not being offered benefits in exchange for relinquishing some portion of her rights. Rather, the law itself is demanding that, instead of accessing the benefits of being in the state, the migrant must forgo those benefits by leaving the state.

To my knowledge, no one has put forward a serious relinquishment argu-

6 Locke, The Second Treatise of Government, ch. viII. Locke's “consent theories" are sometimes characterized as theories of political obligation, but he also intended them to justify political authority. Consent to obey the law does not guarantee the state's authority to enforce obedience to the law. (I can consent to follow the rules of a board game, but that does not give anyone the right to use coercion or force to ensure that I follow those rules.) Thus, a tacit consent theory of territorial authority can be used to justify deportation only if the migrant tacitly relinquishes their right not to be subject to coercion by the state. 
ment. Perhaps, though, the materials for constructing such an argument can be found in Locke's political philosophy. Locke believed that the citizens of a legitimate state have voluntarily relinquished (through express consent) part of their right to liberty (including part of their right to freedom from compulsion) in order to provide the state with the powers it needs to fulfill its proper function. One of those powers is what Locke calls the "federative power," which includes, among other components, the power to make treaties with foreign states. ${ }^{7}$ If this power does exist, then the fact that there are international treaties that require respect for state sovereignty could be used as a premise in a relinquishment argument. For a state's sovereign rights are generally understood to include a right to restrict immigration. Thus, one could argue that the citizens of any legitimate state that is a signatory to a treaty requiring respect for state sovereignty have, through those who exercise the federative power on their behalf, consented to the use of deportation by at least some foreign states (perhaps only signatories to the treaty) to enforce the immigration laws of those states.

Can such an argument succeed? Some political libertarians might doubt that states have a broad, treaty-making power. I do not share that doubt, but I do doubt that an individual citizen who is not acting as an agent of her own state can violate an international treaty to respect the sovereignty of other states. Such a treaty binds only states and, by extension, groups and individuals acting as agents of a state. As agents of their state, for example, an invading foreign army and its members can take part in a state's violation of a treaty requiring respect for the sovereignty of other states. But the individual migrant who, acting on her own behalf rather than as an agent of her state, illegally crosses an international border would neither violate nor participate in the violation of any international treaties that require respect for state sovereignty.

2. Liability arguments. In my judgment, a more promising approach to defending the thesis that the typical deportation does not infringe rights is to argue that the migrant who illegally crosses an international border, or illegally remains in a state, infringes the rights of that state, or the rights of some group within the state, or the rights of at least some of the state's individual citizens or residents. If such an argument is successful, then the typical deportation merely enforces rights, and few would deny that the right to enforce rights limits the right to freedom from compulsion.

We should avoid, however, the common mistake of assuming that if a migrant's illegally entering, or illegally remaining in, a state does infringe rights, then it follows immediately that deportation does not infringe that migrant's rights. In the first place, some rights are unenforceable in the sense that no one

7 Locke, ch. XII, paras. $145-46$. 
has the right to use coercion or force to secure the right in question. If I promise to help you move into your new home, for example, you have a right against me that I help you move, but your use of coercion or force against me to enforce that right would nevertheless infringe my rights. Other rights are enforceable, and that means that the one who infringes or threatens the right is "morally liable" to the use of coercion and force (and to the infliction of harm) to enforce the right in question. Nevertheless, such liability extends only to necessary and proportionate enforcement: unnecessary or disproportionate enforcement still infringes the rights of the liable party. ${ }^{8}$ Thus, a successful "liability argument" must show not only that the migrant who violates immigration law infringes, or poses a threat to, a right, but also that the right in question is an enforceable one, and that deportation is a necessary and proportionate enforcement of that right.

Another relevant distinction here is that between punitive, reparative, and defensive liability. Given that deportation is not a criminal punishment and is not aimed at compensating anyone for a loss, it appears that the relevant sort of liability is liability to defense. (I use "defense" to include both self-defense and defense of others.) Liability to defense is incurred by posing (or taking part in a group's posing) a threat of unjust harm, where one poses a threat of unjust harm if and only if, unless one is prevented from doing so, one will, as a consequence of infringing an enforceable right, damage or at least jeopardize interests protected by that right. ${ }^{9}$ Thus, the success of a liability argument depends on whether the migrant who illegally enters or illegally remains in a foreign state thereby poses a threat of unjust harm, and whether deportation is a necessary and proportionate defensive response to that threat.

Most serious arguments in defense of the suggestion that the typical deportation does not infringe rights are, at least implicitly, this sort of appeal to defensive liability. Indeed, on the assumption that the migrant who illegally crosses a border does not relinquish (or waive) her right not to be deported, perhaps the only possible basis for the conclusion that deporting her would not infringe her rights is the proposition that, because the migrant herself infringes or threatens rights, she is liable to the use of necessary and proportionate coercion or force to enforce the rights she infringes or threatens.

3. Extraordinary limit arguments. It is uncontroversial that both moral liability and relinquishment of rights narrow the scope of the right to freedom from compulsion. But whether there are further limits to that right is controversial. Let us refer to such additional limits, if there are any, as "extraordinary." Some

8 I argue that unnecessary and disproportionate defense infringes rights in Draper, War and Individual Rights, ch. 5 .

9 I argue that defensive liability has this scope in Draper, War and Individual Rights, ch. 3. 
arguments that extraordinary limits exist are motivated by the perception that conventional views about the scope of political authority cannot be justified by appealing only to relinquishment or liability. This same perception, however, can lead to a principled skepticism about political authority. Thus, a convincing appeal to an extraordinary limit must include an adequate defense of the existence of the proposed limit.

One possibility is to appeal to a "non-voluntarist" theory of political authority as a basis for the suggestion that there are extraordinary limits to the right to freedom from compulsion. Some non-voluntarist theories of political authority, however, fall short of justifying the use of coercion or force. On one prominent theory, for example, the authority of the law derives from its instrumental value in helping those subject to that authority do what they ought to do. Thus, Joseph Raz writes:

The normal and primary way to establish that a person should be acknowledged to have authority over another person involves showing that the alleged subject is likely better to comply with reasons which apply to him (other than the alleged authoritative directives) if he accepts the directives of the alleged authority as authoritatively binding, and tries to follow them, than if he tries to follow the reasons which apply to him directly. ${ }^{10}$

Even if such a theory provides a plausible basis for political obligation, and a corresponding limit to the right to liberty, it may not justify deportation. For the mere fact that the law ought to be obeyed is insufficient to show that states are morally permitted to use coercion and force to ensure such obedience. Furthermore, to use such a theory to justify enforcing immigration restrictions, one would need to provide some reason to think that the law can be trusted to provide sound moral advice when it urges migrants not to cross international borders. I doubt that the law provides any moral guidance on such matters. Crossing an international border is not malum in se. Thus, laws that prohibit crossing international borders do not provide guidance about what, independently of the law, an individual ought to do.

Perhaps the most promising sort of extraordinary limit argument would appeal to a "necessity theory" of political authority. Broadly speaking, such a theory attempts to justify political authority, including the right to use coercion and force to execute the law, on the grounds that functioning states are necessary, and a state cannot fulfill its function(s) without an adequate amount of authority to enact and enforce law. Establishing the truth of such a theory is, 
of course, no easy task. But even on the assumption that such a theory is true, there is no guarantee that the theory provides the basis for the conclusion that the typical deportation does not infringe rights. For, pace Hobbes, no plausible theory of political authority, including no plausible necessity theory of political authority, says that the scope of political authority is unlimited. Thus, the assumption that some necessity theory is true still leaves open the question of whether the scope of political authority includes the right to use deportation to enforce immigration law. Furthermore, a theory that grounds political authority in necessity is apt to be ill suited as a basis for the claim that the scope of political authority extends to enforcing unnecessary immigration restrictions. Thus, even in the face of an adequate necessity theory of political authority, the opponent of deportation may be able to make a case that most actual enforcement of immigration restrictions infringes rights. Indeed, some cosmopolitan theorists argue that humanity would be substantially better off with open borders. If they are correct, then one might doubt that a state's authority to close its borders can be grounded in necessity.

4. Indirect arguments. I include in this category any argument that reaches the conclusion that deportation does not infringe rights but does not explain why there is no infringement. Such arguments are likely to be "cantilever arguments" in that they reach their moral conclusion not by identifying the moral principles that ground that conclusion, but rather by "arguing sideways" from moral judgments that are at the same level of generality as the conclusion. ${ }^{11}$ One argument of this sort will be considered in detail in the next section of this paper. The strategy, as we will see, is to argue that at least most of us have beliefs about the scope of a state's authority that commit us to recognizing that, under certain common circumstances, the state has the authority to deport. Although I try to undermine the argument in question, I suspect that the strongest case for the conclusion that the typical deportation does not infringe rights may well be some sort of indirect argument. ${ }^{12}$

The remainder of this paper is an attempt to undermine one indirect argument and three liability arguments. By attacking these arguments, I do not see myself as defending what many refer to as the "libertarian argument for open borders." Indeed, I am not defending open borders at all, nor am I defending the thesis that the typical deportation violates (i.e., unjustifiably infringes) the

11 Miller uses and perhaps coined the expression "cantilever argument" in "Is There a Human Right to Immigrate?" $15-16$.

12

One possibility here that I have not yet seen in the literature would be to argue that one cannot be a skeptic about the right to enforce territorial rights without also being a skeptic about the right to enforce ordinary property rights. 
migrant's right to liberty. I am defending only the more modest thesis that the typical deportation infringes the migrant's right to freedom from compulsion. ${ }^{13}$ One need not be a political libertarian to accept my thesis (and I am not a political libertarian). One need only recognize the existence of a right to freedom from compulsion and doubt the existence of any limit to that right that can be invoked to show that it is not infringed by the typical deportation.

I should add that, although I provide support for the thesis in question, I doubt that it is even possible to conclusively establish its truth. Regardless of how many liability arguments are defeated, for example, it will remain an epistemic possibility that some new argument will demonstrate that, in the typical case, migrants who illegally enter or illegally remain in a state do pose a threat of unjust harm and that deportation is a necessary and proportionate defensive response to that threat. Nevertheless, unless the claim that the migrant does pose such a threat, or for some other reason lacks a right not to be deported, can be shown to be a reasonable one, the presumption must be that deportation would be an infringement of the migrant's rights.

\section{JOSHI'S INDIRECT ARGUMENT}

Recent work by Hrishikesh Joshi suggests the possibility of defeating this presumption by way of an indirect argument (although he does not explicitly advance the argument I have in mind). ${ }^{14}$ Joshi appeals to three kinds of state coercion that most people regard as justified. He argues that if those three kinds of state coercion are justified then, under certain common circumstances, so is the state's use of coercion and force to control its borders.

One of the three is state coercion aimed at preventing negative externalities, and Joshi offers the example of penalizing battery manufacturers that dump the toxic by-products of production into a river. The second is state coercion for the sake of protecting intrinsically valuable things such as national parks. The third is state coercion for the sake of protecting the interests of the domestic population with the lowest socioeconomic status. Establishing serious penalties for

Relying on assumption 3, I am inclined to defend some border enforcement; but I am also inclined to think that most border enforcement in my own nation, the United States of America, violates the right to freedom from compulsion. Some of those violations are horrifically unjust. Detaining people for months or even years pending an immigration hearing, for example, or sentencing migrants to prison for criminally crossing a border, typically involves so great and harmful a deprivation of liberty and such uncertain social benefit that I regard it as an egregious violation of the migrant's basic rights.

14 Joshi, "For (Some) Immigration Restrictions." 
violating minimum wage laws, for example, is accepted by most as a justifiable form of state coercion.

Joshi suggests that all but a few "anarcho-libertarians" believe that state coercion is justified in these three kinds of cases, and he thinks that most of us are therefore committed to the belief that the enforcement of immigration law aimed at protecting the interests of the domestic population with the lowest socioeconomic status, or protecting something intrinsically valuable, or preventing negative externalities, is justifiable. Joshi goes on to show that various immigration restrictions have at least one of these aims. Thus, he takes himself to have shown that, unless the scope of political authority is much narrower than most of us think, using coercion to enforce a variety of actual immigration restrictions is justified.

Even if his argument is sound, it does not settle the issue of concern here. For each of the three uses of coercion to which Joshi appeals might be justified for either of two reasons. First, it might be justified partly because it is within the scope of a state's authority and so does not infringe rights. Alternatively, it might infringe the rights of those subject to it but do so justifiably because it is extremely beneficial. Our interest is in the first possibility. If Joshi is appealing only to the second possibility, then his argument is less interesting, because it would show only that using coercion to enforce certain sorts of immigration restrictions might be beneficial enough to be justified even if such coercion does infringe the rights of migrants. That conclusion is not in dispute, nor should it be. Thus, let us simply assume that Joshi is arguing for the conclusion that state coercion to enforce some immigration restrictions does not infringe rights.

With that assumption in mind, let us assess his argument. The first prong of the argument rests on the suggestion that most of us think that it is within the scope of a state's authority to enact and enforce laws aimed at preventing negative externalities. I suspect that he is right about that, but I want to resist the idea that this commits most of us to the conclusion that it is also within the scope of a state's authority to enact and enforce immigration restrictions aimed at preventing negative externalities. My worry stems from the fact that, as Joshi's example of the battery manufacturer illustrates, laws that prevent negative externalities typically impose penalties on those who would otherwise violate the enforceable rights of others. Thus, Joshi is not in a position to appeal to them as a basis for defending laws that restrict immigration, for he does not take himself to have shown that migrants who are deported are thereby prevented from violating rights. He does claim that immigration's externalities sometimes include rising crime rates, and he uses statistics on crime in Germany and Sweden to 
justify that claim. ${ }^{15}$ But this is not analogous to the case of the battery manufacturer. For in the latter case it is the one who is responsible for the externality who is liable to punishment. Immigration restrictions aimed at reducing crime, on the other hand, are imposed not only on those immigrants who pose a criminal threat of inflicting harm but also on those who do not.

There is another flaw in Joshi's argument that undermines all three of its prongs. Consider, for example, the third prong. Here Joshi begins with the suggestion that most would agree that it is within the scope of a state's authority to use coercion to enforce laws aimed at advancing the interests of the domestic population with the lowest socioeconomic status. That seems right. Few of us would deny the right of a state to establish and enforce minimum wage laws, to use Joshi's example. Moreover, we generally think that the state may enact and enforce minimum wage laws and other laws that regulate the economy even if the expected benefits of such restrictions do not far outweigh their expected costs.

Furthermore, as Joshi points out, immigration restrictions can certainly be enacted for the sake of the economy, including for the sake of economically disadvantaged members of the domestic population. And although the overall economic impact of illegal immigration in various nations is hotly debated, no one doubts that sometimes specific groups of domestic workers are disadvantaged by foreign immigration. Is there not a presumption, then, that immigration restrictions aimed at protecting the economic interests of disadvantaged domestic workers are within the scope of a state's authority and so do not infringe rights?

I concede that, for example, minimum wage laws are within the scope of a state's authority, but Joshi is mistaken if he thinks that this concession commits me to accepting the conclusion that immigration restrictions are also within the scope of a state's authority. For the fact that a state has the authority to restrict the liberty of persons who are within its territorial jurisdiction does not establish that a state has the authority to determine who is within its territorial jurisdiction. Imagine Joshi's argument being applied to justify deporting certain citizens for the sake of providing more economic opportunity for the members of the lowest economic class. I think most of us would resist the conclusion that we are committed to the belief that such forced emigration is within the scope of a state's authority. Minimum wage laws control the behavior of those who reside within the state's territorial jurisdiction. Immigration law determines who is legally permitted to be within the state's territorial jurisdiction. There is a substantial gap between the premise that the former is within the scope of a state's authority and the conclusion that the latter is within the scope of a state's authority. 15 Joshi, "For (Some) Immigration Restrictions," 193. 
This objection to Joshi's argument is substantially buttressed by the fact that, although most if not all extant accounts of territorial jurisdiction imply that a state's controlling in various ways the behavior of persons inside the state is within the scope of a state's territorial authority, several of them do not yield the conclusion that immigration restrictions are within the scope of a state's territorial authority. As we have seen, even a successful tacit consent theory of territorial jurisdiction will fail to justify deportation because the suggestion that the one who is deported has, by accepting benefits from the state that deports her, tacitly consented to her own deportation is implausible. Fair play and gratitude accounts of territorial jurisdiction would also fail to justify deportation because they too depend on the premise that territorial jurisdiction is grounded at least partly in the fact that those subject to it have received benefits from being inside the state. Thus, the question of whether a state, for economic reasons, has the right to use compulsion to exclude people from its territory cannot be answered in the affirmative simply on the basis of the fact that a state has the right to use compulsion to regulate the economic behavior of those persons who are inside its territory. At a minimum, the fundamental question, "What is the correct theory of territorial authority?" cannot be avoided. ${ }^{16}$

Using Joshi's approach, however, someone could argue that, although barriers to trade such as tariffs and embargos typically involve controlling not just what happens within a state but also what goods enter or leave a state, most think that the state is "within its rights" to create them. And if we recognize the state's right to create barriers to international trade, should we not also recognize the state's right to create barriers to international migration?

My response here would be that various accounts of territorial authority, including tacit consent, fair play, and gratitude accounts, are consistent with the conclusion that restricting foreign trade falls within the scope of a state's authority but restricting immigration typically does not. On such accounts, territorially

16 Jeremy Waldron usefully distinguishes two conceptions of a sovereign state ("Exclusion"). On the "Sovereign Ownership conception," a state owns its territory, and its territorial authority is a consequence of that ownership. On the "Sovereign Responsibility conception," a state does not own its territory and its territorial authority is limited to governing the ever-changing human population within its territory. The suggestion that minimum wage laws aimed at benefitting economically disadvantaged domestic workers are within the scope of the state's territorial authority is consistent with each conception. But the suggestion that immigration restrictions aimed at benefitting economically disadvantaged domestic workers are within the scope of the state's authority is consistent only with the Sovereign Ownership conception. Waldron defends the Sovereign Responsibility conception but, regardless of how successfully his defense of that conception of sovereignty is, the point here is that he might well complain that Joshi's argument simply begs the question against the Sovereign Responsibility conception. 
excluding goods is relevantly different from territorially excluding persons. For the individual within a state's territorial jurisdiction who is subjected to the exclusion of her goods is not thereby deprived of the public benefits that, on these accounts, ground the duty to obey the state's laws. But the individual who is subjected to the exclusion of her person is thereby deprived of the public benefits that, on such accounts, ground the duty to obey the law. Thus, the fact that a state has the authority to create barriers to trade does not by itself show that it has the authority to create barriers to immigration. One might object that some states are prepared to bring criminal charges against those who, although they never set foot within that state's territorial jurisdiction, arrange for the illegal movement of even harmless goods across the state's borders. I believe that, in those cases, the state in question has acted beyond the scope of its authority. That belief may be contestable, but it is not at odds with any commonsense views about the scope of state authority that all but a few "anarcho-libertarians" would readily accept.

\section{WELLMAN'S LIABILITY ARGUMENT}

Let us turn our attention to liability arguments. There are many such arguments to be found in the relevant literature, and I cannot address all of them here. I discuss Christopher Heath Wellman's well-known and highly regarded liability argument in this section. ${ }^{17}$ Then, in the final two sections, I discuss two members of the family of liability arguments that, in my opinion, have the best prospects for generating a successful argument to the conclusion that the typical deportation does not infringe rights.

Wellman argues that, because a legitimate state has a right to freedom of association, it also has a right to deport migrants who illegally cross its borders or illegally remain within those borders. He writes:

Legitimate political states are entitled to a sphere of political self-determination, one important component of which is the right to freedom of association. And since freedom of association entitles one to refuse to associate with others, legitimate political states may permissibly refuse to associate with any and all potential immigrants who would like to enter their communities. In other words, just as an individual may permissibly choose whom (if anyone) to marry, and a golf club may choose whom (if 
anyone) to admit as new members, a group of fellow citizens is entitled to determine whom (if anyone) to admit into their country. ${ }^{18}$

Wellman provides a lengthy defense of the claim that a legitimate state has a right to freedom of association. His argument to that intermediate conclusion is admirably clear and rigorous, and I do not engage with it here. I want to take issue, however, with his claim that a state's refusing to allow a potential immigrant to enter or remain in a state is simply an exercise of a state's right to freedom of association, analogous to refusing to marry someone, or refusing to admit new members into a private golf club.

Notice that, as formulated in the quoted passage, Wellman's conclusion is ambiguous. The conclusion could be the claim that a legitimate state has a right to civically or politically exclude, that is, a right to deny to noncitizens the opportunity for citizenship or for political participation. Or the conclusion could be that a legitimate state has a right to territorially exclude, that is, a right to deny noncitizens the opportunity to enter or remain in its territorial domain. Ultimately, Wellman makes it clear that he believes that both conclusions follow from the fact that states have a right to freedom of association. He fails to show, however, that states have a right to use deportation as a means of territorial exclusion. ${ }^{19}$ It might be objected immediately that Wellman does not specifically address deportation, preferring instead to argue only that states have a right to territorially exclude. But Wellman does claim that a state has a right to determine how it will enforce its immigration policies, and so I assume that he believes that deportation falls within the scope of that right. ${ }^{20}$ If I am wrong about that, then I have no quarrel with him.

To use an analogy resembling the one used by Sarah Fine in her excellent critique of Wellman's argument, imagine that the members of Wellman's private golf club meet at a public park to enjoy a picnic. ${ }^{21}$ Because the members of the club do not own the park, their right to freedom of association does not give them the right to demand that no one else enter or remain in the park during their picnic. Analogously, if the state does not own its territory, then the state's right to freedom of association does not give it a right to demand that noncitizens stay off its territory.

18 Wellman and Cole, Debating the Ethics of Immigration, 36.

19 For other criticism of Wellman's arguments in defense of a right to exclude, see Fine, "Freedom of Association Is Not the Answer"; Wilcox, "Do Duties to Outsiders Entail Open Borders?"; Cavallero, "Association and Asylum"; and Blake, "Immigration, Association, and Antidiscrimination."

Wellman and Cole, Debating the Ethics of Immigration, 45.

Fine, "Freedom of Association Is Not the Answer," 354. 
Of course, Wellman is free to argue that a state's right to freedom of association is different from a private golf club's right to freedom of association, and that some important difference between the two explains why the former right includes a right to restrict the freedom of movement of nonmembers in ways that the latter does not. Wellman does not, however, offer such an argument. Thus, he provides no reason to suppose that migrants who illegally cross borders infringe a state's right to freedom of association.

Furthermore, if a state does own its territory and so has a right to territorially exclude on that basis, then any appeal to a right to freedom of association as a basis for territorial exclusion would be superfluous. An analogy here would be a golf club owning its clubhouse: the club members can appeal to their ownership of the clubhouse as a basis for insisting that golfers who are not members of the club exit or refrain from entering the clubhouse. They do not need to appeal to any right to freedom of association, although they might point out that the strength of their interest in associating exclusively with each other is one reason why trespassing would be a significant rather than merely trivial infringement of their property right. By analogy, a state's freedom of association might be a significant interest shielded by its ownership of territory. But then it would be more relevant to whether and when a state's right to territorially exclude is overridden by consequentialist considerations than to the basic question of whether there is a right to territorially exclude. Of course, in a theory of rights, freedom of association might also be put forward as constituting part of the foundation of territorial ownership. Then it would play a crucial role in the argument that, because states own their territory, they have a right to territorially exclude. But Wellman does not propose any such foundational role for freedom of association.

Wellman is aware of this sort of objection, and, responding to Fine, he claims that "the objection can be countered once one appreciates that states are necessarily territorial." He continues:

The familiar but nonetheless crucial point is that because (1) potential conflicts require interaction and (2) we typically interact most extensively with those who are proximate, a set of legal institutions could peacefully settle conflicts only if it has effective authority over all those who are spatially proximate.... And if political unions could not perform their legitimating functions unless they were territorially delineated, there is no reason to be suspicious about the citizens of a given state alleging that their rights to freedom of association entitles them to keep foreigners out of their association and off of their territory. ${ }^{22}$ 
Wellman's argument is not that a state, being necessarily territorial, in some sense owns its territory and so has a territorial right that, like an individual property right, includes a "power of exclusion." Instead, he argues that states are necessarily territorial in the sense of necessarily having jurisdiction in at least one contiguous geographical area. As he puts it, a state cannot perform its function of peacefully settling conflicts unless it "has effective authority over all those who are spatially proximate."

However, even if we concede to Wellman that legitimate states necessarily have territorial jurisdiction, this does not by itself enable him to reach his conclusion that legitimate states have a right to territorially exclude. For a state's having authority over all those within its territory does not imply anything about the scope of that authority in terms of what laws it can legitimately enact and enforce within its jurisdiction. Thus, Wellman's appeal to territorial jurisdiction fails to provide an answer to the question of whether a state has a right to deport those who violate its immigration laws.

Furthermore, even if Wellman could show that the migrant who illegally enters or remains in a state infringes the associational rights of that state (or of its citizens), this would fall well short of showing that deportation is a necessary and proportionate means for enforcing those rights. Again, Wellman claims that a state has a right to determine how it will enforce its immigration policies, but he ought to concede that no state has the right to enact enforcement policies that are unnecessary, disproportionate, or otherwise violate rights. And he does not show that deportation is a necessary and proportionate defense of the right of a state to freedom of association.

Perhaps Wellman should have argued that a state is necessarily territorial in the sense of necessarily owning (in the sense of having a property or property-like right to) the land within its borders. He could then have maintained that, like the owner of private land, a state has an enforceable right to exclude others from entering, or remaining on, the land to which it has a right. Be that as it may, Wellman chose not to offer such an argument. He appeals to a state's right to freedom of association and to territorial jurisdiction, neither of which entail ownership of territory.

\section{MILLER'S LIABILITY ARGUMENT}

Some philosophers do appeal to ownership of some kind to defend at least some deportation. In this section and the next, I want to assess two such arguments, one of them David Miller's and the other Anna Stilz's. ${ }^{23}$ Although there are other

23 Miller, “Territorial Rights”; Stilz, Territorial Sovereignty. 
"ownership arguments" that are also worthy of consideration, I hope that my discussion of Miller's and Stilz's respective efforts will illustrate some of the kinds of challenges such arguments face. ${ }^{24}$

Neither Miller nor Stilz uses the term "ownership" to describe the rights to which they respectively appeal. Thus, let me be clear that my use of the term "ownership" may well be broader than theirs. On my use of the term, those who seek to defend a state's right to deport on grounds of ownership need not claim that ownership of territory and ordinary private ownership of land are exactly alike in terms of the nature, strength, or basis of the respective ownership claims. (Similarly, those who speak of self-ownership need not claim that self-ownership and ownership of external property are closely akin in any of these ways.) They do, however, need to appeal to some right that resembles a property right in certain crucial respects. Thus, when I speak of "appropriation" or "ownership" of territory, I am speaking of acquiring or enjoying a property or property-like right to territory that includes at a minimum two component rights that are also components of ordinary property rights: first, an enforceable right to occupy and use the land in question, and second, an enforceable right to physically exclude others from that land. I will call the first of these component rights a right of occupation and use and the second a right against trespass.

Miller argues that nations (and indigenous peoples) are the primary bearers of territorial rights and that states enforce the territorial rights of the nations they govern. He proposes that "when a group has interacted with the land in such a way as to increase its value, this gives the group a prima facie right to hold the land so as to be able to enjoy the enhanced value-to reap the fruits of the cultivated land or to travel down the roads they have built."25 The increase in value is not solely economic or material. Miller emphasizes that a nation's historical sites, national monuments, landmarks, etc., can have deep symbolic meaning so that a nation losing its territory "would be to lose much that is of symbolic value to the group, and therefore essential to its continuing identity as a people." 26

Miller's justification for both a nation's right of occupation and use and its right against trespass is, however, only partly a backward-looking appeal to the nation's historical success in increasing the material and symbolic value of land. It is also partly a present and forward-looking appeal to the interest a nation has in enjoying today and in the future the value of the land that, historically, the nation has enhanced. Miller emphasizes the strength of that interest, even going so far as to suggest that when "land has been shaped in a way that reflects the

24 See, for example, Simmons, Boundaries of Authority; Nine, "A Lockean Theory of Territory."

25 Miller, "Territorial Rights," 259.

26 Miller, "Territorial Rights," 259. 
group's distinctive culture, continued occupancy of that land becomes essential if the group is to live a flourishing life." 27 This appeal to interests plays an especially important role in his argument that nations have a right against trespass. Miller proposes that, given that the members of a nation have a "deep interest in the territory as the repository of their cultural values," the presence in that territory of too many people, or too many people of another culture, can make it "impossible for land to be used in the way the group's values require." And if citizenship is to be granted to long-term residents (Miller assumes that it must), then the presence of too many immigrants may ultimately lead to the state's decisions being shaped partly by cultural values foreign to the nation, which, again, could undermine a nation's interest in using the land in ways that reflect its own culture and values. ${ }^{28}$

Miller's argument is a serious one, but I am unconvinced that a right against trespass can be established in this way. Setting aside possible theoretical concerns about interest-based theories of rights, I believe that Miller has not shown that the interest a nation has in excluding outsiders is sufficiently powerful to generate a right against trespass in spite of the countervailing interests that outsiders might have in not being excluded. The strength of those countervailing interests should not be underestimated. They are capable of motivating people to take the risks associated with illegal immigration, to migrate to a land whose cultural values are foreign to them, to leave behind family and friends, and to abandon their homeland in spite of the fact that it is the repository of their own cultural values. It is far from obvious, then, that the interests that motivate such sacrifices are generally less weighty than the interests to which Miller appeals in his attempt to establish an interest-based right against trespass. Thus, I think it is fair to say that his argument is incomplete.

I concede, however, that I have not shown that the argument cannot be completed. Thus, let us grant for the moment Miller's Lockean principle that a group can acquire territory by increasing the material and symbolic value of the land its members occupy. As we have seen, Miller wants to move from that principle of appropriation to the conclusion that nations typically own territory. Such ownership, which includes an enforceable right against trespass, can then serve as the basis for arguing that the typical deportation does not infringe rights. There are, however, several obstacles in Miller's path.

One of them arises from the fact that not every member of a nation that increases the value of land contributes to that increase. This fact makes it unclear why every member of a nation should share in the collective ownership of ter-

Miller, “Territorial Rights,” 260.

Miller, “Territorial Rights," 265. 
ritory. Miller anticipates this sort of concern and replies to what he describes as "the objection which asks how later generations who inherit land can claim rights to territory that they have not themselves improved." Ultimately, his reply appeals to the present and forward-looking dimension of his argument. Thus, although he concedes that "living on historically improved land is in one sense an undeserved benefit," he points out that "being excluded from that land is certainly an undeserved loss." 29

Miller's theory does, however, exclude from collective ownership those citizens of a state who are not members of the nation that has increased the value of the relevant land. That seems to leave them as second-class citizens no less vulnerable to exclusion than the citizens of other states. Moreover, given that many of these citizens have themselves contributed to enhancing the land, it seems unfair to exclude them from the class of joint territorial right holders-especially since some members of that class have not made any contribution at all.

The general problem here for theories of territorial ownership, the problem of citizen exclusion, is that of identifying a principle of territorial appropriation that does not exclude certain classes of citizens from the collective that is supposed to own territory. A related problem, the problem of noncitizen inclusion, is that of identifying a principle of territorial appropriation that does not include noncitizens or even those illegally residing in a state as members of the collective that owns territory. In Miller's case, the latter problem is that, in most cases where (some) members of a nation have enhanced the land they occupy, many people who are not members of that nation will have also made contributions to enhancing that same land, including some who illegally reside there, and even some foreign persons who have never set foot on the land that they have improved from afar. Thus, it seems that Miller's principle of territorial appropriation leads to the conclusion that many immigrants who illegally reside on the land occupied largely by the members of a nation, and even some foreign nonresidents, are among the joint owners of the territory that, according to him, is owned by that nation.

These difficulties concern the identity of the joint owners of territory, but Miller also faces difficulties concerning the boundaries of the territory that is owned. Given that many nation-states claim as territory land the value of which has not been improved by anyone, it is unclear how Miller can justify claiming that a nation owns all of the territory the state claims on its behalf. Borrowing Stilz's expression "ancillary territory" to describe territory that is neither occupied nor used, I refer to the general problem here as the problem of ancillary territory. The problem is especially significant because of the tremendous amount of

29 Miller, “Territorial Rights," 260-61. 
undeveloped and unoccupied land that states such as the United States claim as territory. Indeed, it is difficult to imagine a principle of territorial appropriation whose reach could extend to all the ancillary territory of the United States. Miller concedes that his Lockean principle of appropriation cannot ground a right to ancillary territory, but he appeals to the value of efficiency to fill the gap:

It should be conceded that a considerable degree of historical contingency enters into the precise placing of state boundaries. This should not disturb us so long as we continue to accept the general justifying argument for the territorial state. It belongs to that argument that state boundaries should be clear, continuous and in normal cases reasonably straight for reasons of efficiency. ${ }^{30}$

This response is inadequate, however, because, even if territorial jurisdiction in ancillary territory might be defensible on grounds of efficiency, it is not at all clear that an enforceable right against trespass can be justified on such grounds. ${ }^{31}$

Another kind of problem that any attempt to establish collective ownership of territory must solve emerges because most nations and the states that represent them did not acquire their territory by satisfying some reasonable criteria for territorial appropriation. Instead, they used force or coercion to seize land from earlier inhabitants. Miller is well aware of this problem of bad pedigree, and he concedes that "a nation cannot gain territorial rights simply by displacing another people and then undertaking some value-creating activities in the place in question."32 But he never explicitly offers a solution to the problem. He does say that acquiring territorial rights requires long occupation because the necessary transformation of the land takes many years to achieve. Thus, on his account, when a nation appropriates territory that it originally seized by force, it does so long after those who unjustly took the land from others are dead. Perhaps, then, one could argue on his behalf that those who are not at fault for any historical injustice are the ones who, because they have enhanced the land that was originally stolen, collectively acquire a territorial claim to it. ${ }^{33}$ That solution seems

30 Miller, “Territorial Rights," 263.

31 Even if Miller were to restrict his defense of ownership of territory to "core territory," one could still question whether Miller's theory can justify national ownership of territory. The problem is that different groups within a nation, perhaps exemplifying different subcultures, have enhanced the value of different parts of the nation's territory. Hence, Miller needs to explain why his principle of appropriation does not lead to the conclusion that a nation's core territory should be carved up into smaller territories, each owned by a subset of the nation's members.

Miller, “Territorial Rights," 261.

Miller, “Territorial Rights," $258-62$. 
plausible enough, but if Miller were to embrace it, then he would be walking a fine line. For if a nation's past usurpation of territory does not invalidate its current claim to that territory, then one wonders why a nation's past enhancement of land can play any role in establishing the current validity of that claim.

A related difficulty that I call the problem of forfeiture stems from the fact that many nations and states have failed to respect the sovereignty and territorial rights of others. Thus, they may have forfeited any right they would otherwise have to demand that others respect their own territorial rights. Given the extent to which, historically, the United States has interfered in the internal affairs of Guatemala, for example, it would be difficult to take seriously a justification for deporting Guatemalan immigrants that was based on the claim that Guatemalans must respect the sovereignty of the United States.

It appears, then, that Miller's ownership argument is unconvincing even if we grant him his principle of appropriation. Furthermore, that principle itself can be challenged on the grounds that it is too broad, for it appears to permit the appropriation of land that is already privately owned. I cannot acquire a claim to your land by enhancing it, nor can any group do so. If, for example, I (or a group to which I belong) enhance the material value of your land by raising bees that, foreseeably, pollinate your vegetation, I do not thereby acquire a claim to your land or its vegetation, nor should I. Thus, Miller's argument is once again, at best, incomplete, for it lacks an explanation of how a nation can acquire ownership of territory that includes parcels of land privately owned by individual members (or even nonmembers) of that nation. I call the problem of providing such an explanation the problem of overlapping ownership. ${ }^{34}$

\section{STILZ'S LIABILITY ARGUMENT}

Ownership arguments like Miller's rely on an attempt to identify a principle of territorial appropriation to serve as a basis for the claim that some collective, either a nation (Miller's view) or a state (a common alternative view), owns

34 It is also important to keep in mind that, even if nations or states do own the land that they claim as territory, and so illegal immigration (typically) infringes a nation's right against trespass, reaching the conclusion that the typical deportation does not infringe rights would still require showing that deportation is a necessary and proportionate means of enforcing that right. That is no easy task. After all, most migrants who illegally reside in a state do not prevent others from, to echo Miller, reaping the fruits of the cultivated land or traveling down the roads they have built. Nor do they pose a serious threat to the symbolic value of the land. I suspect that only in rare cases would the threat posed by immigration be serious enough that the harm that is inflicted by the typical deportation would be proportionate to that threat. 
territory. As Miller's argument illustrates, however, it is no easy task to find a plausible principle of territorial appropriation that assigns ownership of the right geographical area (problem of ancillary territory) to the right collective (problems of citizen exclusion and noncitizen inclusion) in spite of that collective's moral shortcomings (problems of bad pedigree and forfeiture) and in spite of the fact that much of the territory in question is also privately owned (problem of overlapping ownership).

Stilz's ownership argument avoids most of these problems because she does not attempt to show that a state or a nation owns territory. Rather, employing an interest-based account of rights, she argues that, by having place-based interests in land, individuals acquire what she calls "occupancy rights." These pre-institutional rights include a right to occupy and use the "area fundamental to their located life plans" and a right to exclude others from occupying that area should such occupation set back those plans. In my terms, then, Stilz's occupancy rights include, as components, both a right of occupation and use and a right against trespass. They are, therefore, ownership rights, and, on her view, the state's right to enact and enforce immigration restrictions is a right to enforce these ownership rights. ${ }^{35}$

Because she is not trying to establish collective ownership of territory, the problems of citizen exclusion and noncitizen inclusion do not arise. On her view, most but not all citizens and some noncitizens have occupancy rights within the territorial jurisdiction of the state. Because one of the state's core functions is to protect the rights of those within its territorial jurisdiction, she concludes that the state sometimes fulfills one of its core functions through deportation. The problem of overlapping ownership also does not arise because the state's right to enforce occupancy rights does not require the state's acquiring ownership of the land to which individuals have pre-institutional ownership rights. As for the problem of bad pedigree, Stilz readily concedes that occupancy rights do not include a power to exclude others from occupying land that has been unjustly seized from them. Although issues of correcting historical injustices enter in here and complicate matters, at worst Stilz's view requires only qualification to accommodate the relevant claims. Furthermore, her view is better equipped to solve the problem of forfeiture than views that posit national or state ownership of territory because her occupancy rights are held by individuals who typically are not responsible for even the contemporary injustices of the nation or state to which they belong, let alone any historical injustices.

Stilz does struggle with the problem of ancillary territory, however, because most ancillary territory is not fundamental to anyone's "located life plans" and 
so, on her view, no one acquires a right of occupancy to it. She hints at the possibility of a necessity account of why, in at least some cases, states have a right to exclude foreign persons from ancillary territory, but, ultimately, she concedes that some states may lack that right. ${ }^{36}$ Nevertheless, if she can establish that a state has a right to exclude foreign persons from its core territory, this is still a very significant conclusion, because many states have little or no ancillary territory and, even in states that do, foreign migrants are seldom to be found there.

Although I find Stilz's approach to be promising, I want to challenge the principle of appropriation at the foundation of her argument. That principle is offered as an improvement on Locke's principle of first appropriation and, following Locke, Stilz recognizes what she calls a "fair use proviso" intended to accommodate the idea that everyone has an equal initial claim to natural resources, including land. Specifically, she says that an occupancy right does not include a right to exclude those who cannot enjoy flourishing located life plans where they are now and, in order to enjoy such plans, must occupy an area to which others have occupancy rights. ${ }^{37} \mathrm{I}$ want to argue that this proviso is too narrow, and so her principle of appropriation is too broad.

Stilz's proviso is an example of what I call a "same use proviso," for she proposes that land can be appropriated to be used to advance located life plans so long as others have an equal opportunity to use land in the same way, namely, to advance their own located life plans. Locke's proviso that "enough and as good" must be left for others is sometimes interpreted as a "same use proviso." So understood, Locke was proposing that, if one is to appropriate a previously unowned resource for a certain use, one must leave "enough and as good" of that resource for others to appropriate for that same use. But resources, including parcels of land, often have multiple potential uses. Thus, even if a same use proviso is in place in Locke's state of nature, this would not prohibit someone from appropriating all of the land that is available for a specific purpose so long as that person does not use the land for that purpose. Suppose, for example, that I want to appropriate land for farming. A same use proviso would require me to leave enough land that is just as suitable for farming so that others have the same opportunity to farm that I have. But now suppose that, although I satisfy that requirement, the land I appropriate contains a rare, medicinally useful moss that would be destroyed by farming. A same use proviso would create no obstacle to my appropriation of that land for farming even though that appropriation would potentially deny others the opportunity to meet their medical needs. Or suppose that the land I want to appropriate for farming must be crossed to access 
the only local pass through a mountain range. Again, if there is plenty of land equally suitable for farming left for my neighbors, and I have no interest in travel, a same use proviso would not block my appropriation of the land in question.

This strikes me as a basis for doubting that Locke understood his own proviso as a same use proviso. He took very seriously the difficulty of justifying first appropriation of land, for he understood that every first appropriation of land diminishes the rights of all but the appropriating party by restricting the scope of the right to liberty of others and by making others liable to coercion and force should they commit a trespass on the appropriated land. Moreover, if we begin with the assumption that land is collectively owned by all until it is removed from the commons for private use, then every appropriation reduces what is owned in common and hence reduces all but the appropriator's share of resources.

In response to the challenge of justifying first appropriation, Locke sought to show that incentivizing productive labor by allowing appropriation on its basis benefits nearly everyone and that even those who do not benefit still have no basis for complaint because, so long as "enough and as good" is left for others, appropriation is "of no prejudice to any [person]." If Locke's argument is to make sense, then we must interpret "enough and as good" broadly enough so that first appropriations that do not violate the proviso are genuinely of no prejudice to anyone. A same use interpretation of the proviso fails to do that. In my two examples, appropriation of the land in question would be "of prejudice" to those who wanted to use the land in question for certain purposes other than farming - medicine in the first example, and travel across the mountain range in the second.

Setting aside the question of how to interpret Locke, I see no more reason to suppose that Stilz's principle of appropriation should be limited only by a same use proviso than there is to suppose that Locke's principle for first appropriation should have only that limitation. The supposition that, so long as everyone has a place to pursue located life plans, individuals or groups can, by acquiring occupancy rights, create substantial obstacles to travel, economic opportunity, access to family, etc., is inconsistent with recognizing the equal initial claim that everyone has to unowned resources.

Stilz might contest this by appeal to her interest-based theory of rights. Thus, she could argue that human interests are better served by a same use proviso than by a more restrictive proviso. But can such a claim be adequately evidenced? Stilz recognizes that to "argue for a moral right of occupancy, we must compare the strength of the interests protected under the proposed right against the strength of possible countervailing considerations." ${ }^{38}$ I would add that, in 
making such an assessment, it is important to keep separate the two components of Stilz's moral right of occupancy. Much of what she says in defense of this right is a defense of its first component: the right to occupy and use the area fundamental to one's located life plans. In citing the powerful interests that she believes justify occupancy rights, for example, she rightly points out that removing someone from his home and community "destroys many of his life plans at once." ${ }^{39}$ But the interest in not being removed from one's home supports only the first component of an occupancy right, and the right to deport requires the second component: the right to exclude others from occupying (i.e., entering or remaining in) that area should such occupation set back the located life plans of current occupants. It is here where I remain unconvinced that the balance of interests is so heavily tipped toward current occupants as opposed to potential occupants that, on an interest-based theory of rights, the right to exclude ought to be recognized. (I also reject interest-based theories of rights, but that is a longer story.) Stilz herself points out that the desire to relocate can be motivated by the most fundamental autonomy interests - a desire to escape political oppression, the desire to join one's family, the desire to pursue a career that is not an option in one's own country, etc. - as well as by more trivial interests. ${ }^{40}$ The desire to exclude outsiders from one's territory can also be motivated by fundamental interests - an interest in limiting economic competition, an interest in crime reduction, etc. - as well as by more trivial interests. ${ }^{41} \mathrm{I}$ do not see any basis for thinking that, on balance, the latter interests are so much weightier than the former that they ought to be protected by a right that would undermine the former interests and would generate liability to coercion and force in the form of deportation.

Furthermore, if we begin with common ownership of resources in a state of nature, as Stilz does, appealing to speculations about what would best serve interests overall is not good enough. ${ }^{42}$ One cannot justify depriving me of what we jointly own on the grounds that your interest in exclusive ownership is weightier than my interest in joint ownership. To put it in Lockean terms, recognizing the second component of Stilz's occupancy rights is "of prejudice" to many. Of course, in extreme cases, unrestricted immigration could completely and disastrously undermine the most vital interests of those who reside in some area. But then assumption 3 would come into play and we could say that, although immi- 
gration restrictions would infringe the rights of would-be immigrants to this area, the benefits of such restrictions are so great that the restrictions are justifiable.

\section{CONCLUSION}

Stilz or Miller may have an adequate response to my objections, or there might be a way to modify one of their positions to overcome those objections, or perhaps other ownership arguments will succeed even if theirs do not. Furthermore, there may be some other kind of liability argument, or perhaps an indirect, relinquishment, or extraordinary limit argument, that establishes that the typical deportation does not infringe rights. At this moment, however, it seems to me that the presumption that the typical deportation infringes rights has not been defeated. And that means that I am morally opposed to, and even prepared to use necessary and proportionate force or coercion to prevent, most deportations.

University of Delaware kai@udel.edu

\section{REFERENCES}

Blake, Michael. "Immigration, Association, and Antidiscrimination." Ethics 122, no. 4 (July 2012): 748-62.

Cavallero, Eric. "Association and Asylum." Philosophical Studies 169, no. 1 (May 2014): 133-41.

Draper, Kaila. War and Individual Rights. New York: Oxford University Press, 2012.

Fine, Sarah. "Freedom of Association Is Not the Answer." Ethics 120, no. 2 (January 2010): $338-56$.

Joshi, Hrishikesh. "For (Some) Immigration Restrictions." In Ethics, Left and Right: The Moral Issues That Divide Us, edited by Bob Fischer, 191-98. New York: Oxford University Press, 2019.

Locke, John. The Second Treatise of Government, edited by Thomas P. Peardon. New Jersey: Prentice Hall, 1997.

Miller, David. "Is There a Human Right to Immigrate?" In Migration in Political Theory: The Ethics of Movement and Membership, edited by Sarah Fine and Lea Ypi, 11-31. Oxford: Oxford University Press, 2016.

. "Territorial Rights: Concept and Justification." Political Studies 60, no. 2 (2012): 252-68. 
Nine, Cara. "A Lockean Theory of Territory." Political Studies 56, no. 1 (2008): $148-65$.

Raz, Joseph. Ethics in the Public Domain: Essays in the Morality of Law and Politics. Oxford: Clarendon Press, 1995.

Simmons, A. John. Boundaries of Authority. Oxford: Oxford University Press, 2016.

Stilz, Anna. Territorial Sovereignty. Oxford: Oxford University Press, 2019.

Waldron, Jeremy. "Exclusion: Property Analogies in the Immigration Debate." Theoretical Inquiries in Law 18, no. 2 (2017): 469-89.

Wellman, Christopher Heath, and Phillip Cole. Debating the Ethics of Immigration: Is There a Right to Exclude? New York: Oxford University Press, 2011.

Wilcox, Shelly. "Do Duties to Outsiders Entail Open Borders? A Reply to Wellman." Philosophical Studies 169 (May 2014): 123-32. 